УДК 619:618

DOI 10.33943/MMS.2020.80.52.011

\title{
СРАВНЕНИЕ СЕРОЛОГИЧЕСКИХ МЕТОДОВ ЛАБОРАТОРНОЙ ДИАГНОСТИКИ ЛЕЙКОЗА КРУПНОГО РОГАТОГО СКОТА
}

\author{
МИХАЙЛОВА В.В. \\ ЛОБОВА Т.П., кандидат биологических наук \\ СКВОРЦОВА А.Н., ШИШКИНА М.С. \\ ФГБУ Центральная научно-методическая ветеринарная лаборатория \\ ГЛУШАКОВА Н.А. технический директор \\ ООО «ВерУмБио»
}

Дана сравнительная характеристика серологических методов лабораторной диагностики вируса лейкоза крупного рогатого скота. Проведена оценка нескольких коммерческих тест-систем ИФА по критериям специфичности, чувствительности и воспроизводимости с использованием ресерентных образцов, соответствующих стандартам ОІЕ (МЭБ).

Ключевые слова: вирус лейкоза крупного рогатого скота, серологические методы диагностики, реакция иммунодиффузии, иммуноферментный анализ.

Вирус лейкоза крупного рогатого скота (ВЛКРС) до сих пор является актуальной проблемой в молочном скотоводстве. Ущерб, наносимый заболеванием, обусловлен не только гибелью высокопродуктивных животных и утилизацией туш с генерализованными поражениями, затратами на лабораторные исследования, мероприятиями по профилактике и ликвидации этого заболевания, но и достаточно высокими экономическими потерями, в том числе и в племенной работе. Помимо этого сокращаются эксплуатационные сроки крупного рогатого скота, падают удои, качество молока, растет себестоимость продукции [1].

По требованиям Международного эпизоотического бюро, инфицированные вирусом лейкоза и гематологически больные животные, а также молоко, мясо и другие продукты убоя, полученные от них, не могут находиться в обороте и использоваться для пищевых целей на территории Таможенного союза и стран-участниц ВТО.

В настоящее время еще не разработана специфическая профилактика против ВЛКРС [2]. Поэтому необходимо в краткие сроки выявлять заболевших животных, а также вирусоносителей, для того чтобы эффективно проводить противолейкозные мероприятия.

На сегодняшний день в лабораторной практике наиболее распространенным методом диагностики ВЛКРС является реакция иммунодиффузии в агаровом геле (РИД). Она основана на обнаружении в сыворотке крови специфических преципитирующих АТ, которые появляются в крови через 2-8 недель после заражения животного ВЛКРС и сохраняются в организме пожизненно. Реакция иммунодиффузии имеет свои преимущества - обладает достаточно высокой специфичностью и небольшой стоимостью реагентов, но она же имеет и ряд недостатков - более низкая чув- ствительность в сравнении с ИФА (то есть возможны пропуски положительных животных) [4]; визуальный учет результатов (возможна субъективная оценка); учет результатов только через 48 ч после постановки реакции.

В настоящий момент кроме реакции иммунодиффузии часто используется метод непрямого иммуноферментного анализа (ИФА). Он основан на связывании специфических к вирусу лейкоза АТ с АГ ВЛКРС, комплекс АТ-АГ выявляется с помощью видоспецифических антител, меченых пероксидазой хрена, с последующим ферментативным превращением бесцветного субстрата в окрашенный продукт [3]. Результаты можно получить в течение нескольких часов, оценка их осуществляется с помощью спектрометрического оборудования. Положительные результаты серологических исследований на обнаружение антител к ВЛКРС (ИФА, РИД) достаточны для того, чтобы стадо получило статус инфицированного вирусом лейкоза, но не стоит исключать гематологические исследования для выявления стадии клинического поражения крови при данном заболевании.

Целью исследований являлось выявление тест-системы, наиболее чувствительной и специфичной $\mathrm{k}$ лейкозу КРС. В задачу исследований входили сравнительные испытания различных методов и тест-систем.

Материалы и методы. На базе ФГБУ ЦНМВЛ были проведены сличительные испытания трех коммерческих наборов ИФА, которые предназначены для выявления ВЛКРС: Leukosis serum screening Ab test Kit (IDEXX), ID Screen BLV Competition (IDvet); набора для выявления антител к вирусу лейкоза крупного рогатого скота (ВЛКРС) методом иммуноферментного анализа (ИФА) VeriTest (ООО «Ветбиохим») и одного набора для серологической диагностики лейкоза КРС методом РИД 
Результаты сравнения тестов

\begin{tabular}{|c|c|c|c|c|}
\hline \multirow{2}{*}{ Показатель } & \multicolumn{4}{|c|}{ Тест-система } \\
\hline & IDEXX & IDVet & ВБX & РИД \\
\hline Контрольные образцы & $\begin{array}{c}+1,198- \\
0,304\end{array}$ & $\begin{array}{c}+0,109- \\
0,888\end{array}$ & $\begin{array}{c}+1,519- \\
0,159\end{array}$ & $\begin{array}{l}\text { согласно } \\
\text { инструкции }\end{array}$ \\
\hline \multirow{5}{*}{$\begin{array}{l}\text { Enzootic Bovine Leukosis (EBL) } \\
\text { OIE Reference Serum E05 } \\
\text { (нативная сыворотка) }\end{array}$} & 3,667 & 0,100 & 1,656 & \multirow{5}{*}{$\begin{array}{l}\text { все } 5 \text { проб } \\
\text { положительные } \\
4\end{array}$} \\
\hline & 3,596 & 0,087 & 1,671 & \\
\hline & 3,580 & 0,085 & 1,572 & \\
\hline & 3,648 & 0,074 & 1,597 & \\
\hline & $3,731 \cup$ & 0,1194 & $1,606 \uplus$ & \\
\hline Среднее значение (М) & 3,644 & 0,093 & 1,620 & 0 \\
\hline Стандартное отклонение (б) & 0,05 & 0,02 & 0,04 & 0 \\
\hline Коэффициент вариации (Cv),\% & 1 & 18 & 2 & 0 \\
\hline \multirow{5}{*}{$\begin{array}{l}\text { Enzootic Bovine Leukosis (EBL) } \\
\text { OIE Reference Serum E05 } \\
\text { (разведение 1:10) }\end{array}$} & 3,154 & 0,186 & 0,983 & \multirow{5}{*}{$\begin{array}{l}\text { все } 5 \text { проб } \\
\text { положительные } \\
\qquad\end{array}$} \\
\hline & 3,126 & $0,931 \bigcirc$ & 0,859 & \\
\hline & 3,062 & 0,266 & 0,836 & \\
\hline & 3,690 & 0,237 & 0,925 & \\
\hline & $3,035 \cup$ & 0,2044 & 0,9084 & \\
\hline Среднее значение (М) & 3,2134 & 0,3648 & 0,9022 & - \\
\hline Стандартное отклонение (б) & 0,24 & 0,28 & 0,05 & - \\
\hline Коэффициент & 8 & 78 & 6 & - \\
\hline \multirow{5}{*}{$\begin{array}{l}\text { Enzootic Bovine Leukosis (EBL) } \\
\text { OIE Reference Serum E05 } \\
\text { (разведение 1:100) }\end{array}$} & 1,145 & 0,63 & 0,177 & \multirow{5}{*}{$\begin{array}{l}2 \text { пробы - } \\
\text { отрицательные, } \\
3 \text { пробы } \\
\text { сомнительные } \\
2\end{array}$} \\
\hline & 1,457 & 0,614 & 0,163 & \\
\hline & 1,740 & 0,644 & 0,190 & \\
\hline & 1,593 & 0,541 & 0,234 & \\
\hline & $1,543 \Theta$ & 0,559 & $0,208 \bigcirc$ & \\
\hline Среднее значение (М) & 1,496 & 0,600 & 0,194 & - \\
\hline Стандартное отклонение (б) & 0,20 & 0,04 & 0,02 & - \\
\hline Коэффициент вариации $\left(\mathrm{C}_{\mathrm{V}}\right), \%$ & 13 & 7 & 13 & - \\
\hline \multirow{5}{*}{$\begin{array}{l}\text { Enzootic Bovine Leukosis (EBL) } \\
\text { OIE Reference Serum } \\
\text { Е05(Разведение 1:1000) }\end{array}$} & 0,272 & 0,775 & 0,079 & \multirow{5}{*}{$\begin{array}{l}\text { все } 5 \text { проб } \\
\text { отрицательные } \\
{ }^{-}\end{array}$} \\
\hline & 0,257 & 0,767 & 0,076 & \\
\hline & 0,258 & 0,790 & 0,078 & \\
\hline & 0,255 & 0,795 & 0,067 & \\
\hline & $0,261 \odot$ & $0,839 \bigcirc$ & $0,071 \bigcirc$ & \\
\hline Среднее значение (М) & 0,261 & 0,793 & 0,074 & - \\
\hline Стандартное отклонение (б) & 0,01 & 0,03 & 0,00 & - \\
\hline Коэффициент вариации $\left(\mathrm{C}_{\mathrm{V}}\right), \%$ & 2 & 3 & 6 & - \\
\hline
\end{tabular}

Из вышеперечисленного можно сделать вывод, что при исследовании набором производства IDEXX, который обладает более высокой чувствительностью, выявление животных, имеющих антитела к ВЛКРС, будет осуществляться в гораздо более ранние сроки после заражения.

При изучении фетальной сыворотки Hyclone в пяти повторах все используемые в опыте тест-системы дали отрицательный результат, что свидетельствует о высоком уровне специфичности данных наборов.

Из сказанного выше можно сделать вывод, что при выявлении антител к ВЛКРС наиболее чувствительной коммерческой тест-системой оказалась IDEXX Leukosis serum screening Ab test Kit. Для выбора метода исследования необходимо руководствоваться, в первую очередь, чувствительностью и специфичностью тест-систем, так как оздоровление поголовья крупного рогатого скота от лейкоза является одной из приоритетных государственных программ. К сожалению, не все лаборатории в настоящее время могут использовать рекомендованные тесты из-за недостаточной оснащенности оборудованием и квалификации специалистов, и эта проблема требует своего скорейшего решения.

В заключение хотелось бы отметить, что для наиболее достоверной оценки статуса стада и своевременного выявления заболе-

(ФКП Курская Биофабрика, БИОК). Испытания были проведены и проанализированы в соответствии с инструкциями производителей. В качестве исследуемого материала для оценки чувствительности применяли peфрерентную сыворотку Enzootic Bovine Leukosis (EBL) OIE Reference Serum E05. При изучении специфичности была использована стандартная эмбриональная телячья сыворотка Hyclone (US Origin).

Для тестирования использованы в пяти повторах разведения сыворотки Enzootic Bovine Leukosis (EBL) OIE Reference Serum E05: 1:10 [Европейский Союз требует обнаружения антител в стандартной сыворотке E05 в разведении 1:10, только после этого тест-системы могут быть лицензированы для диагностических целей (Всемирная Ассамблея МЭБ, 2016)], 1:100 и $1: 1000$.

Полученные результаты представлены в таблице. Как видим, при исследовании цельного референтного контроля Enzootic Bovine Leukosis (EBL) OIE Reference Serum E05, все наборы ИФА и РИД дали положительный результат. При разведении в соотношении $10^{-1}$ наборы IDEXX, «Ветбиохим» и РИД дали положительный результат. B 1 пробе при использовании набора IDVet был получен отрицательный результат, что и сказалось на повышении коэффициента вариации. Но уже при разведении референтного контроля в соотношении 1:100, положительный результат при исследовании всех образцов был получен только на наборе IDEXX, у набора IDvet была 1 сомнительная проба; при исследовании методом РИД было получено 2 отрицательных и 3 сомнительных результата, набор производства «Ветбиохим» показал отрицательные результаты по всем исследуемым образцам. вания обязательно нужно учитывать и результаты гематологических исследований у серологически положительно реагирующих животных.

\section{ЛИТЕРАТУРА}

1. Fenner, F. / F. Fenner, E.J. Dubovi, N.J. Maclachlan. - 4th ed. // Fenner's Veterinary Virology. - Academic. - 2011. - 264 s. 2. Rodríguez, S.M. Preventive and therapeutic strategies for bovine leukemia virus: Lessons for HTLV / S.M. Rodríguez, A. Florins, N. Gillet [et al.] // Viruses. - 2011. - № 3(7). - S. 1210-1248. 3. Kravchuk, M.B. Methodological Instructive Regulations for Guidelines for the diagnosis of cattle leukemia / M.B. Kravchuk. - 2000. - № 13-7-2/2130. - C. 1-27. 4. Martin D. Comparative study of PCR as a direct assay and ELISA and AGID as indirect assays for the detection of bovine leukaemia virus / D. Martin, A. Arjona, I. Soto [et al.] // J. Vet Med - 2001. - № 48. - C. 97-106.

E-mail: cnmvl@cnmvl.ru cto@verumbio.ru

COMPARISON OF SEROLOGICAL METHODS OF LABORATORY DIAGNOSIS OF BOVINE LEUKOSIS VIRUS MIKHAILOVA V.V., LOBOVA T.P., SKVORTSOVA A.N., SHISHKINA M.S.

FGBU Central Science-methodic Veterinary Laboratory

\section{GLUSHAKOVA N.A.}

VerumBio LLC

This article presents a comparative study of serological methods for laboratory diagnostics of bovine leukemia virus. Several commercial ELISA test were evaluated for specificity, sensitivity, and repeatability using reference samples which meets OIE standards.

Key words: bovine leukemia virus, serological diagnostic methods, reaction of immunodiffusion, enzyme-linked immunosorbent assay. 